\title{
PENINGKATAN KUALITAS KEASAMAN (pH) PADA SUMBER AIR UNTUK INDUSTRI AIR MINERAL DENGAN METODE PENYARINGAN
}

\section{THE IMPROVEMENT OF ACIDITY QUALITY (pH) IN WATER SOURCE FOR THE MINERAL WATER INDUSTRY WITH FILTRATION METHOD}

\author{
Sukma Budi Ariyani ${ }^{1 *}$ ), Asmawit ${ }^{2)}$, Pramono Putro Utomo3), \\ Heru Agus Cahyanto ${ }^{4)}$ \\ 1,2,3,4) Baristand Industri Pontianak JIn. Budi Utomo No. 41 Pontianak 78243 \\ *e-mail : sukma-ariyani@kemenperin.go.id
}

Diterima : 29 April 2020; Direvisi : 25 Juni 2020 ; Diterbitkan : 03 Agustus 2020

\begin{abstract}
Good quality water is a necessity for living things for their survival. Mineral water sources for industry raw materials include groundwater and surface water. The quality of the ground water taken from Anjongan Subdistrict, Mempawah District, West Kalimantan, which was used as a water source did not meet the acidity value requirement $(\mathrm{pH})$ following the Health Ministerial Regulation No. 416 / MENKES / IX / 1990 as tested by one of mineral water companies in West Kalimantan as required by SPPT SNI. The purpose of this study was to increase the $\mathrm{pH}$ value of source water so that it is suitable for use as raw water. Three types of filter material, namely, quartz sand, manganese sand, and activated carbon, were used to increase the $\mathrm{pH}$ value. The results showed that the water that was filtered using activated carbon increased the $\mathrm{pH}$ value by increasing the percentage of $18.7 \%$, increasing the $\mathrm{pH}$ from 5.68 to 6.74 so that it met the quality standard ( $\mathrm{pH}$ 6.5-9); while filtering with sand manganese and quartz sand, the result of the increase in $\mathrm{pH}$ did not meet the standards. Local governments could offer solutions to improve the quality of raw water acidity to other companies with the same obstacles in the company.
\end{abstract}

Keywords: activated carbon, filtration, $\mathrm{pH}$, water

\begin{abstract}
ABSTRAK
Air dengan kualitas yang baik merupakan kebutuhan makhluk hidup yang harus dipenuhi demi keberlangsungan hidupnya. Sumber air untuk bahan baku industri air mineral diantaranya berasal dari air tanah dan air permukaan. Kualitas air tanah yang diambil dari Kecamatan Anjongan, Kabupaten Mempawah, Kalimantan Barat yang digunakan sebagai sumber air tidak memenuhi persyaratan nilai keasaman $(\mathrm{pH})$ sesuai Peraturan Menteri Kesehatan Nomor 416/MENKES/IX/1990 sebagaimana telah dilakukan pengujian sumber air tersebut oleh salah satu perusahaan air mineral di Kalimantan Barat sebagai syarat untuk pengurusan SPPT SNI. Tujuan penelitian ini adalah meningkatkan nilai pH air sumber sehingga layak digunakan sebagai air baku. Tiga jenis bahan penyaring yaitu pasir kuarsa, pasir mangan dan karbon aktif digunakan untuk menaikkan nilai $\mathrm{pH}$. Hasil penelitian menunjukkan bahwa air yang yang disaring menggunakan karbon aktif mengalami peningkatan nilai $\mathrm{pH}$ dengan persentase peningkatan $18,7 \%$, menaikkan $\mathrm{pH}$ dari 5,68 menjadi 6,74 sehinnga memenuhi standar mutu ( $\mathrm{pH} 6,5-9)$, sedangkan penyaringan dengan pasir mangan dan pasir kuarsa, hasil kenaikan $\mathrm{pH}$ nya masih belum memenuhi standar. Pemerintah daerah dapat menyampaikan solusi peningkatan kualitas keasaman air baku ke perusahaan-perusahaan lainnya yang memiliki kendala yang sama di lapangan.
\end{abstract}

Kata kunci: air, karbon aktif, penyaringan, $\mathrm{pH}$ 


\section{PENDAHULUAN}

Air merupakan sumber daya yang sangat diperlukan oleh makhluk hidup untuk memenuhi berbagai kebutuhan secara alami. Kebanyakan penduduk Indonesia menggunakan air permukaan terutama air sungai dan air sumur untuk memenuhi kebutuhan air sehari hari (Quddus, 2014).

Tingginya pencemaran air sumur saat ini sangat mempengaruhi kehidupan manusia dan lingkungan terutama dalam penggunaan air bersih yang semakin lama semakin menurun kuantitasnya. Hal tersebut berdampak terhadap perusahaan air mineral di Kalimantan Barat yang jauh dari mata air gunung. Perusahaan air mineral tersebut menggunakan air sumur sebagai sumber air baku, di mana air sumur saat ini kualitasnya semakin menurun.

Salah satu perusahaan air mineral di Kabupaten Mempawah Kalimantan Barat menggunakan sumber air dari sumur bor di daerah Anjongan untuk memproduksi air mineral. Sumur bor dibuat dengan cara pengeboran lapisan air tanah yang lebih dalam sehingga persentase terkontaminasi menjadi kecil (Yuliani et al., 2017). Tiga tahun terakhir diketahui sumber air yang digunakan tingkat keasamannya rendah yakni, antara 56 , sehingga perlu dilakukan pengolahan terlebih dahulu agar layak dijadikan sumber air untuk industri air mineral. Perusahaan telah melakukan metode penyaringan dengan batu apung dan ijuk, tetapi hasilnya masih di bawah standar Peraturan Menteri Kesehatan Republik Indonesia No. 416/Menkes/Per/IX/1990 yakni hanya menaikkan $\mathrm{pH}$ dari 5,81 menjadi 5,95.

Secara umum, air dengan $\mathrm{pH}$ rendah keasamannya (kurang dari 6) bersifat korosif. Air seperti ini dapat menyebabkan kerusakan secara langsung pada pipa logam dan tempat pembuangan. Konsumsi air minum dengan kualitas yang rendah dapat menyebabkan efek jangka panjang terhadap kesehatan. Air yang memiliki derajat keasaman tinggi tidak baik untuk pencernaan karena dapat menyebabkan beberapa jenis penyakit misalnya, diare, kontraksi otot lambung, kerusakan pada gigi, dan penyakit kulit (Asriza et al., 2018)

Air baku yang digunakan untuk produksi air mineral harus memenuhi standar kualitas mengacu Permenkes RI No. 416/MENKES/IX/1990. Parameter kualitas air terbagi menjadi kualitas fisik, kimia, dan bebas dari mikroorganisme. Air yang memenuhi parameter fisik adalah air yang tidak berbau, tidak berasa, tidak berwarna, tidak keruh atau jernih dan dengan suhu sebaiknya di bawah suhu udara sedemikian rupa sehingga menimbulkan rasa nyaman, dan jumlah zat padat terlarut (TDS) yang rendah.

Jika ditinjau berdasarkan parameter kimia, hendaknya air tersebut tidak mengandung zat-zat kimia yang beracun, ataupun kandungan logam yang melebihi baku mutu air bersih (Situmorang \& Lubis, 2017). Menurut Permenkes tersebut, standar mutu $\mathrm{pH}$ yang ditetapkan adalah antara 6,5-9. Jika pH sumber air yang digunakan di bawah 6,5, maka harus dilakukan peningkatan kualitas terlebih dahulu. Menurut hasil penelitian terdahulu, metode filtrasi dapat meningkatkan kualitas $\mathrm{pH}$ air (Mashadi et al., 2018).

Filtrasi atau penyaringan adalah suatu proses untuk menghilangkan zat padat tersuspensif yang diukur dengan kekeruhan air melalui media berpori. Penyaringan melalui media berpori terjadi dengan cara menghambat partikel-partikel ke dalam ruang pori sehingga terjadi pengumpulan dan tumpukan partikel tersebut pada permukaan butiran media. Tumpukan partikel yang melekat pada butiran 
media ini akan membuat air tidak keruh dan menjadi lebih bersih (Mashadi et al., 2018).

Hasil filtrasi dipengaruhi juga oleh media filtrasi yang digunakan. Karbon aktif adalah bahan yang umum digunakan untuk pemurnian dan pemisahan kontaminan dari cairan atau uap. Selama ini, karbon aktif banyak dipergunakan untuk menyerap bahan-bahan organik. Karbon aktif menghilangkan substansi dari air dengan cara adsorpsi. Karbon aktif menggunakan proses penyerapan fisik di mana gaya Van der Waals menarik bahan organik dari larutan ke permukaan karbon aktif dan dihilangkan dari larutan (Heriyani \& Mugisidi, 2016). Arang aktif dapat mengadsorpsi gas dan senyawasenyawa kimia tertentu atau sifat adsorpsinya selektif (melakukan pemilihan), dan tergantung pada besar atau volum pori-pori dan luas permukaan. Daya serap arang aktif sangat besar yaitu, 25-100\% terhadap berat arang aktif (Rahmadhani, 2014). Suhendra \& Rianto, (2017) dan Fadhillah \& Wahyuni (2016) menyatakan bahwa pada proses filtrasi dengan penambahan arang aktif terjadi penambahan nilai $\mathrm{pH}$ yang cukup tinggi. Dengan demikian, selain digunakan sebagai bahan penyerap, arang aktif juga dapat digunakan untuk menaikkan nilai $\mathrm{pH}$ pada air. Hal tersebut yang melatarbelakangi pelaksanaan penelitian ini menggunakan karbon aktif sebagai salah satu media filtrasi, bukan dengan media filtrasi pasir kuarsa dan pasir mangan.

Pasir kuarsa memiliki kekerasan 7 skala Mohs, berat jenis 2,65, titik lebur $1715^{\circ} \mathrm{C}$, bentuk kristal hexagonal dan konduktivitas panas $12-100^{\circ} \mathrm{C}$. Pasir kuarsa sangat efektif dalam menyaring lumpur dan bahan pengotor air lainnya (Mugiyantoro et al., 2017), sedangkan pasir mangan merupakan material yang berfungsi sebagai adsorben, penukar ion dan buffer (penyangga) (Oesman \& Sugito, 2017). Menurut hasil penelitian Pinem (2019), penyaringan dengan menggunakan media pasir berpengaruh terhadap peningkatan nilai $\mathrm{pH}$.

Penelitian ini bertujuan untuk meningkatkan kualitas $\mathrm{pH}$ pada sumber air yang digunakan untuk produksi air mineral agar sesuai dengan standar baku mutu yang ditetapkan dengan metode penyaringan dan memperoleh karakteristik bahan penyaring yang digunakan.

\section{METODE PENELITIAN}

Penelitian ini dilakukan di Laboratorium Proses Baristand Industri Pontianak selama 6 bulan yakni bulan Juni hingga November 2019. Untuk pengujian SEM-EDX dan FTIR dilakukan pada Laboratorium Terpadu UNDIP Semarang.

Bahan yang digunakan adalah air yang diperoleh dari sumur bor di daerah Anjongan Kabupaten Mempawah, pasir kuarsa, pasir mangan, dan karbon aktif yang masing-masing perlakuan menggunakan 300 gram bahan penyaring. Alat penelitian yang digunakan diantaranya beaker glass, corong pemisah, buret, statis, oven merek Memert dan pHmeter portable merek Hach.

\section{Prosedur Penelitian}

Sampel air terlebih dahulu diuji nilai pHnya. Variabel yang berubah pada penelitian ini adalah jenis bahan penyaring yang digunakan yakni, pasir kuarsa, pasir mangan dan karbon aktif. Bahan penyaring sebelum digunakan dicuci dahulu, dikeringkan dalam oven suhu $60^{\circ} \mathrm{C}$ selama 24 jam dan masingmasing diuji karakteristiknya dengan uji SEM-EDX dan FTIR. 
Prinsip metode yang digunakan adalah metode filtrasi seperti pada penelitian Mashadi et al., (2018). Namun, metode penyaringan yang digunakan dalam penelitian ini adalah metode filtrasi satu stage. Sampel air $300 \mathrm{ml}$ dilewatkan pada 300 gram pasir kuarsa (ketinggian $5 \mathrm{~cm}$ ). Setelah proses penyaringan tersebut terjadi, $\mathrm{pH}$ diukur kembali Hal yang sama dilakukan dengan bahan penyaring pasir mangan dan karbon aktif. Rangkaian alat penelitian bisa dilihat pada Gambar 1.

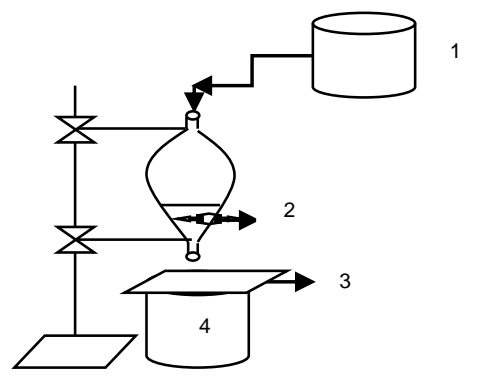

Keterangan :
1. Air Sumber
2. Bahan Penyaring
3. Kertas Saring
4. Hasil Penyaringan

Gambar 1. Rangkaian Alat Penelitian

HASIL DAN PEMBAHASAN

Karakterisasi Karbon

Aktif

Menggunakan SEM-EDX dan FTIR.

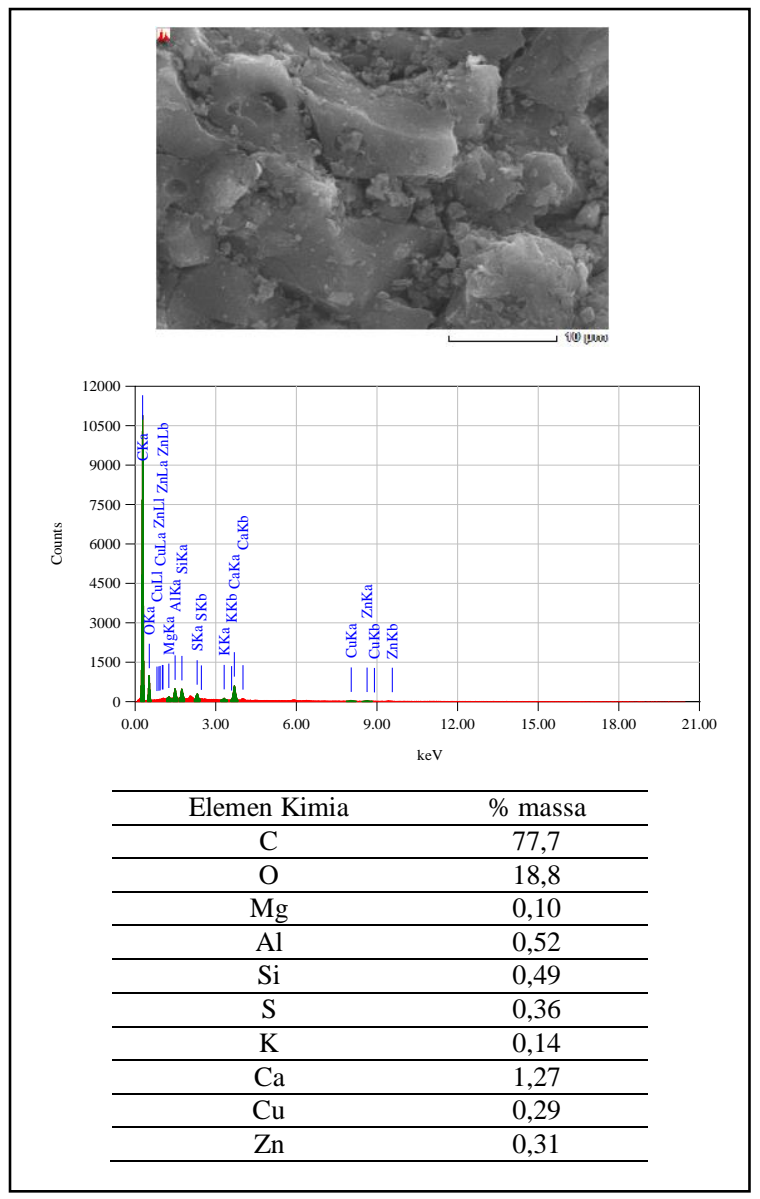

Gambar 2. Hasil Uji SEM-EDX Karbon Aktif
Pada umumnya, karbon aktif memiliki porositas pada permukaannya. Hasil uji dengan menggunakan alat SEM menunjukkan bahwa pori-pori yang terdapat pada karbon aktif dapat dilihat (Gambar 2). Semakin banyak pori porinya, maka semakin banyak pula penyerapan yang akan terjadi. Pada sisi lain, hasil analisis komposisi dengan menggunakan EDX menunjukkan bahwa karbon aktif mengandung 10 elemen kimia dan yang terbanyak adalah elemen kimia $\mathrm{C}$ dan $\mathrm{O}$.

Hasil FTIR diinterpretasikan menggunakan tabel daerah gugus fungsi pada IR seperti pada Skoog et al. (1998). Karbon aktif memiliki pita serapan pada gelombang $2660,33 \mathrm{~cm}^{-}$ 1 yang mengidentifikasikan adanya gugus $\mathrm{O}-\mathrm{H}$ (hidroksil) tipe senyawa monomer asam karboksilat dan memiliki pita serapan pada gelombang $1546,41 \mathrm{~cm}^{-1}$ yang mengidentifikasikan adanya gugus $\mathrm{C}=\mathrm{C}$ tipe senyawa cincin aromatik (Gambar 3). Dapat diketahui bahwa karbon aktif tersebut memiliki gugus fungsi yang dapat melakukan pengikatan dengan ion logam. Gugus fungsi tersebut adalah gugus hidroksil (Ningsih et al., 2016). 


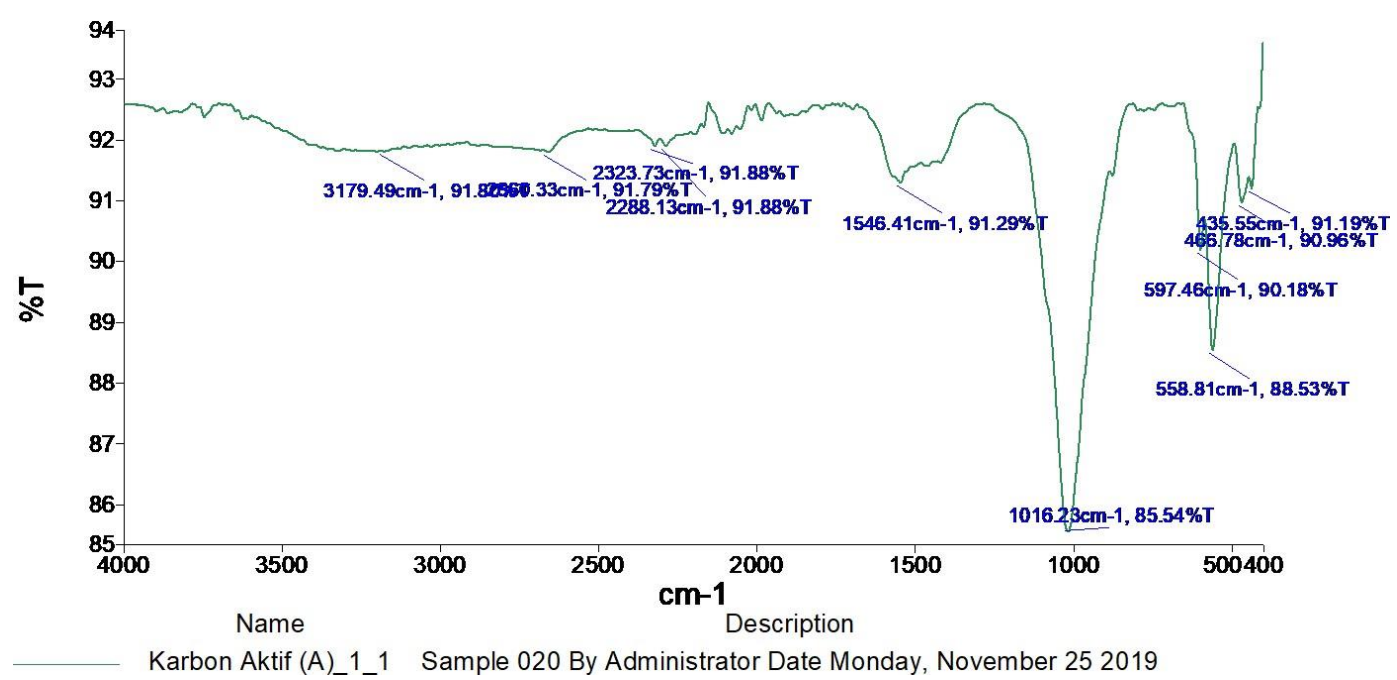

Gambar 3. Hasil Uji FTIR dari Karbon Aktif yang Digunakan

\section{Karakterisasi Pasir Kuarsa Yang Digunakan Menggunakan SEM-EDX dan FTIR.}

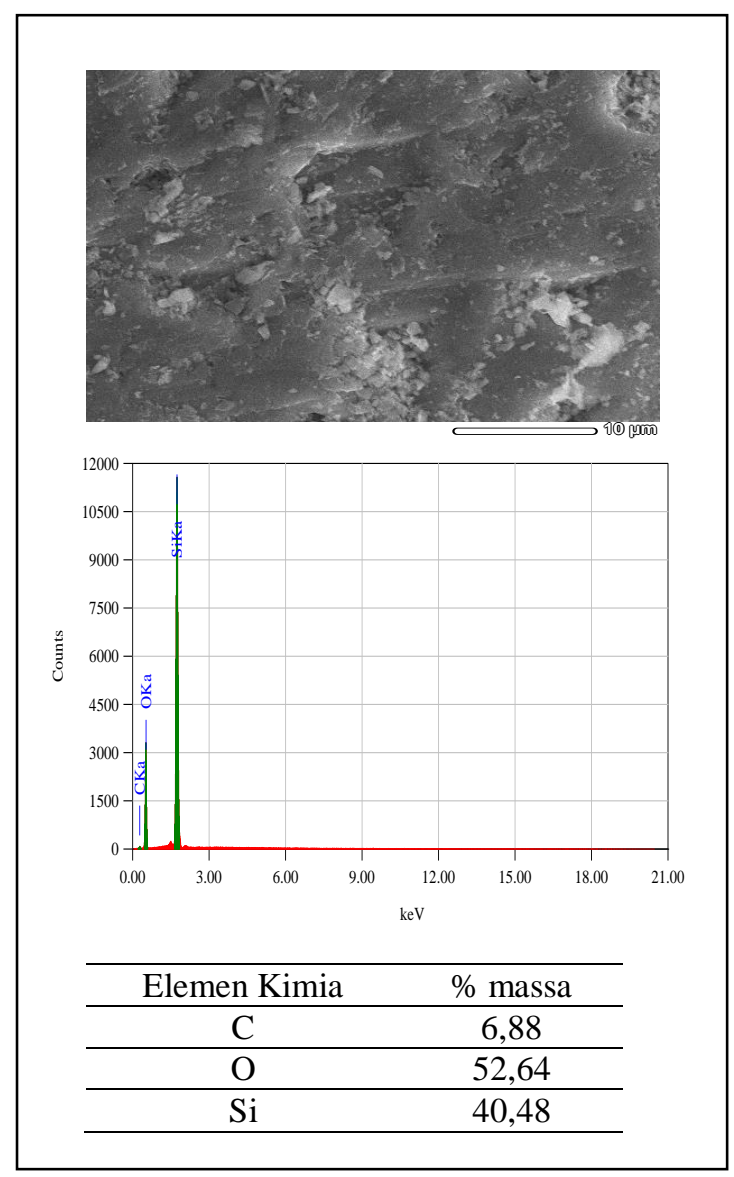

Gambar 4. Hasil Uji SEM-EDX Pasir Kuarsa yang Digunakan
Pasir yang digunakan harus memenuhi kualitas yang baik karena kualitas bahan penyaring akan mempengaruhi hasil penyaringan (Majid, 2019). Dari hasil pengujian SEM di atas, pori-pori yang terdapat pada pasir kuarsa dapat dilihat seperti pada Gambar 4. Elemen kimia penyusun pasir kuarsa hanya terdiri dari 3 (tiga) elemen kimia yakni, C, O dan Si. Elemen terbanyak adalah $\mathrm{O}$, kemudian Si dan yang paling sedikit persentase massa nya adalah elemen C. Silika oksida yang berlebihan dapat berfungsi sebagai oksidator (Agustina, 2019).

Hasil uji FTIR (Gambar 5) menunjukkan bahwa pasir kuarsa memiliki pita serapan pada gelombang $465,29 \mathrm{~cm}^{-1}$ yang mengidentifikasikan adanya gugus fungsi vibrasi tekuk $=\mathrm{Si}-$ O pada (=Si-O-Si=), memiliki pita serapan pada gelombang $796,12 \mathrm{~cm}^{-1}$ yang mengidentifikasikan adanya gugus fungsi vibrasi ulur simetris dari $=\mathrm{Si}-\mathrm{O}$ pada $(=\mathrm{Si}-\mathrm{O}-\mathrm{Si}=)$ dan juga memiliki pita serapan pada gelombang $1084,99 \mathrm{~cm}^{-1}$ yang mengidentifikasikan adanya gugus fungsi vibrasi ulur asimetris dari $=\mathrm{Si}-\mathrm{O}$ pada $(=\mathrm{Si}-\mathrm{O}-\mathrm{Si}=)$ (Trisko et al., 2013). 


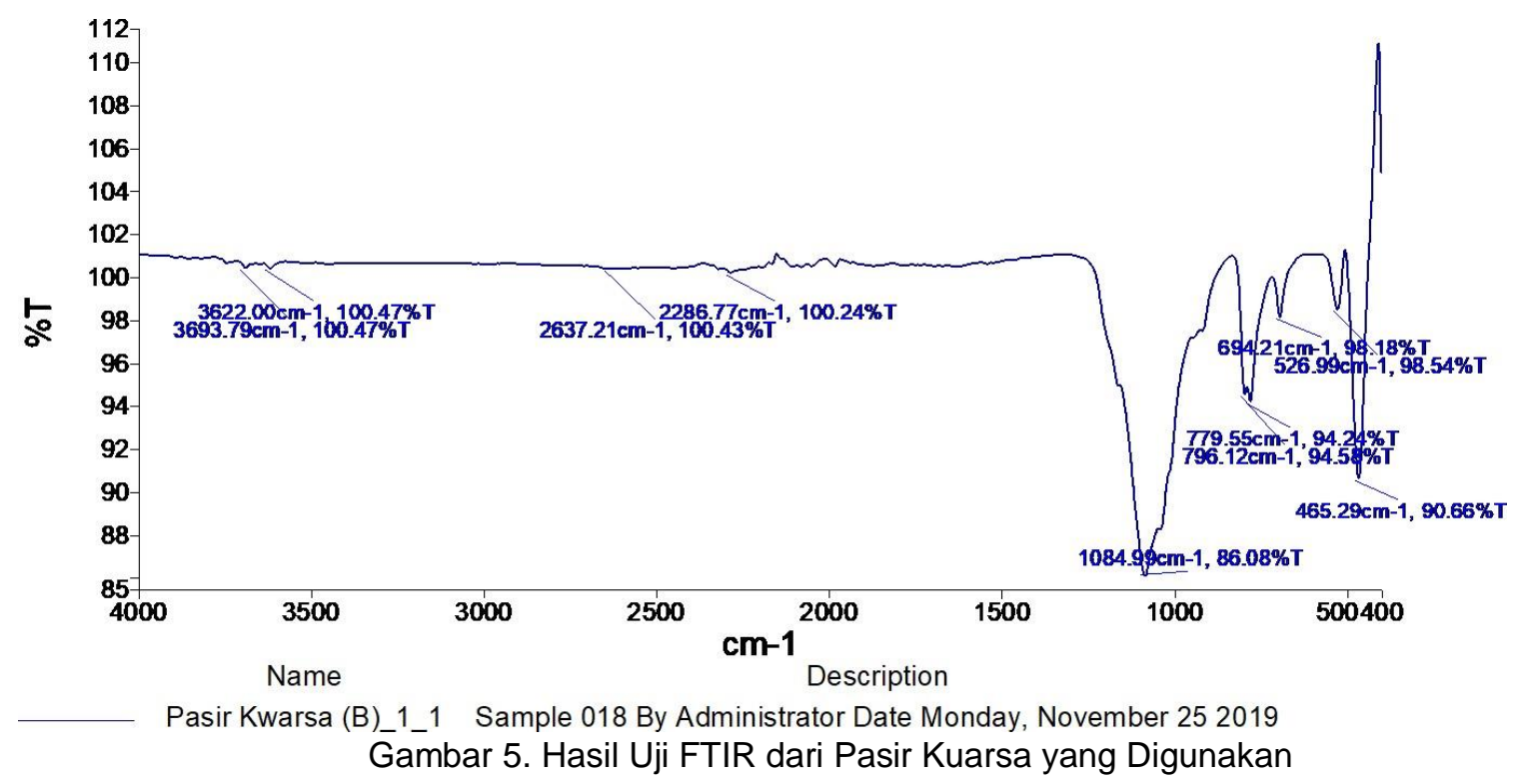

Karakterisasi Pasir Mangan

Menggunakan SEM-EDX dan FTIR.

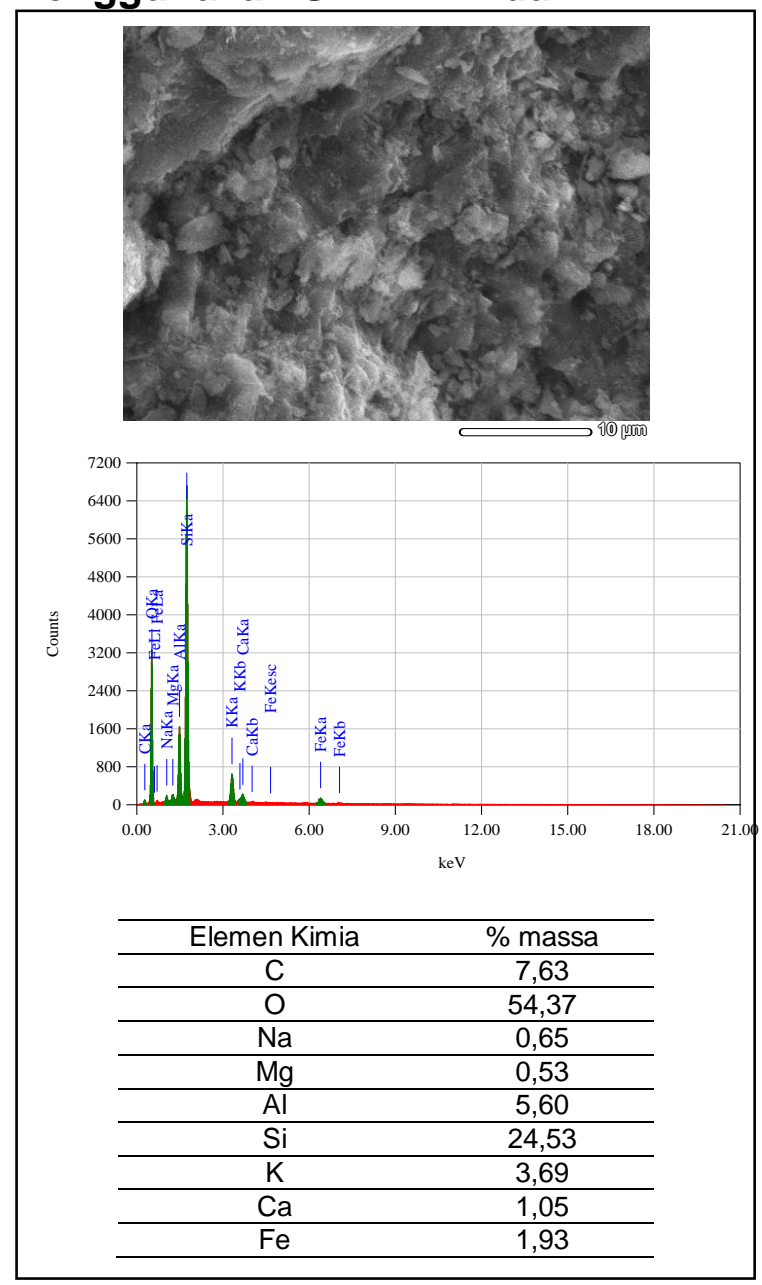

Gambar 6. Hasil Uji SEM-EDX Pasir Mangan yang Digunakan

Dari hasil pengujian SEM, dapat dilihat bahwa pasir mangan memiliki pori-pori seperti pada Gambar 6. Pasir mangan mengandung 10 elemen kimia dan yang terbanyak dalam pasir mangan adalah elemen kimia $\mathrm{O}$ dan Si. Pasir mangan adalah pasir yang berfungsi untuk menghilangkan kandungan mangan, besi atau hidrogen sulfida yang tampak seperti lapisan atas berminyak di dalam air.

Hasil uji FTIR (Gambar 7) menunjukkan bahwa pasir mangan memiliki pita serapan pada gelombang $3406,76 \mathrm{~cm}^{-1}$ yang mengidentifikasikan adanya gugus $\mathrm{O}-\mathrm{H}$ tipe senyawa fenol dan gugus $\mathrm{N}-\mathrm{H}$ tipe senyawa amina, memiliki pita serapan pada gelombang $2642,64 \mathrm{~cm}^{-1}$ yang mengidentifikasikan adanya gugus $\mathrm{O}-\mathrm{H}$ tipe senyawa monomer asam karboksilat, memiliki pita serapan pada gelombang 1638,91 $\mathrm{cm}^{-1}$ yang mengidentifikasikan adanya gugus $\mathrm{C}=\mathrm{C}$ tipe senyawa alkena, memiliki pita serapan pada gelombang $1543,01 \mathrm{~cm}^{-1}$ yang mengidentifikasikan adanya gugus $\mathrm{C}=\mathrm{C}$ tipe senyawa cincin aromatik dan memiliki pita serapan pada gelombang 777,30 $\mathrm{cm}^{-1}$ yang mengidentifikasikan adanya gugus $\mathrm{C}-\mathrm{H}$ tipe senyawa alkena dan cincin aromatik. 


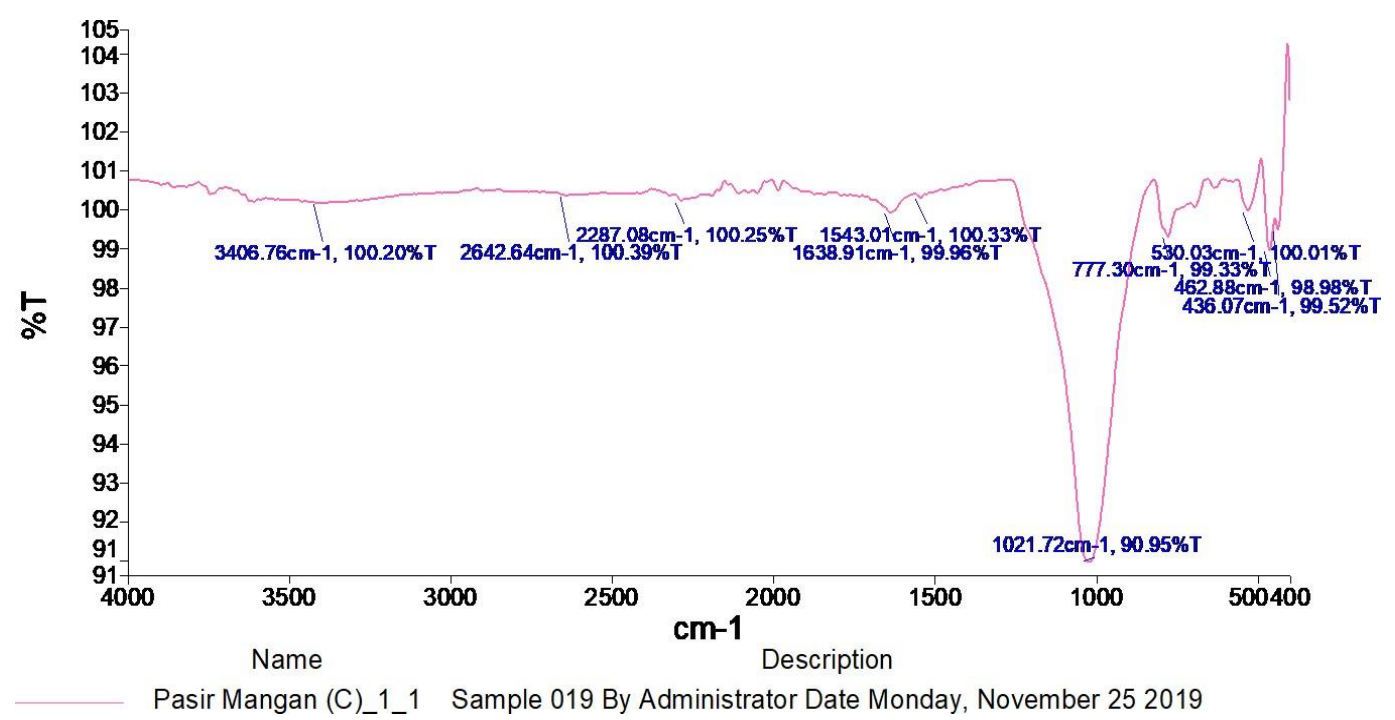

Gambar 7. Hasil Uji FTIR dari Pasir Mangan yang Digunakan

\section{Hasil Uji pH Sampel Air}

Tabel 1. Hasil Uji pH Sampel Air

\begin{tabular}{llcc}
\hline No. & $\begin{array}{l}\text { Bahan } \\
\text { Penyaring }\end{array}$ & $\begin{array}{c}\text { Nilai pH } \\
\text { Awal }\end{array}$ & $\begin{array}{c}\text { Nilai pH } \\
\text { Akhir }\end{array}$ \\
\hline 1 & Pasir Kuarsa & 5,68 & 5,90 \\
\hline 2 & Pasir Mangan & 5,68 & 6,31 \\
\hline 3 & Karbon Aktif & 5,68 & 6,74
\end{tabular}

Hasil nilai $\mathrm{pH}$ pada Tabel 1. merupakan rerata dari pengulangan percobaan sebanyak 3 kali. Hasil yang diperoleh menunjukkan bahwa proses penyaringan dengan karbon aktif yang terbukti efektif untuk meningkatkan kualitas $\mathrm{pH}$ air sehingga memenuhi standar mutu air bersih sesuai Peraturan Menteri Kesehatan RI No. 416/MENKES/IX/1990 yakni 6,5-9. Hal ini disebabkan pada proses filtrasi, unsur logam dalam air akan diuraikan menjadi ion-ion logam dan ion hidroksida [OH-]. Ion-ion logam akan ditarik karbon aktif dengan gaya Van der Waals sehingga yang tertinggal adalah ion [OH-]. (Heriyani \& Mugisidi, 2016).

Karbon aktif berfungsi juga sebagai penyerap bahan-bahan organik yang terdapat dalam sampel air sumur bor. Bahan-bahan organik dapat terkandung di dalam air sumur. Air yang mengandung senyawa organik terlarut mengakibatkan air tersebut bersifat asam (Suhendra et al., 2012). Oleh karena itu, dengan adanya penyerapan bahan organik oleh karbon aktif, nilai pH dapat naik.

Hasil yang diperoleh dari penyaringan dengan media pasir kuarsa dan pasir mangan juga dapat meningkatkan $\mathrm{pH}$ walaupun kurang signifikan. Peningkatan $\mathrm{pH}$ ini disebabkan oleh adanya penyaringan dengan menggunakan media pasir yang dapat menurunkan kekeruhan air. Kekeruhan air yang rendah akan menyebabkan tingginya oksigen yang bisa diikat pada air sehingga air tersebut memiliki Dissolved Oxygen (DO) yang tinggi. Kadar DO yang tinggi pada air berpengaruh dalam peningkatan nilai $\mathrm{pH}$ karena apabila kadar DO rendah menyebabkan kadar $\mathrm{CO}_{2}$ yang dihasilkan dari respirasi mikroorganisme semakin tinggi dan tidak digunakan, maka akan menghasilkan ion $\mathrm{H}+$ yang menyebabkan $\mathrm{pH}$ menjadi rendah (Pinem, 2019).

Bahan penyaring yang digunakan dalam penelitian ini bisa dilihat pada Gambar 8. 


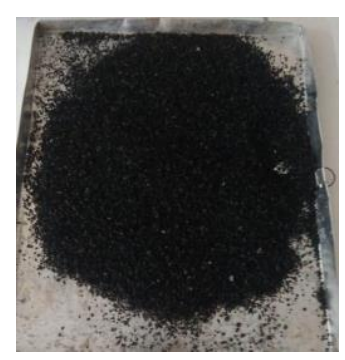

(a)

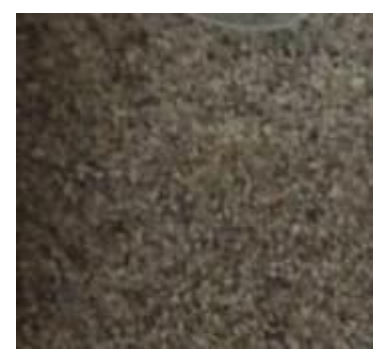

(b)

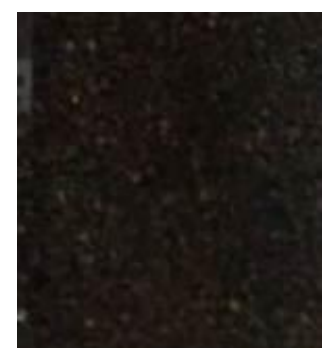

(c)

Gambar 8. (a) karbon aktif; (b) pasir kuarsa dan (c) pasir mangan

\section{Persentase Kenaikan pH}

Gambar 9. menunjukkan bahwa persentase kenaikan nilai $\mathrm{pH}$ dengan bahan penyaring karbon aktif paling tinggi dibandingkan dengan bahan penyaring pasir kuarsa dan pasir mangan. Hasil yang diperoleh menunjukkan bahwa bahan penyaring karbon aktif dapat menaikkan nilai $\mathrm{pH}$ air sebesar $18,7 \%$ dari $\mathrm{pH}$ awal sehingga memenuhi standar baku mutu Peraturan Menteri Kesehatan RI No. 416/MENKES/IX/1990 ( $\mathrm{pH}=6,5-9)$, dimana untuk memenuhi standar tersebut, diperlukan kenaikan $\mathrm{pH}$ sebesar $14,5-58,5 \%$. Bahan penyaring pasir kuarsa dapat menaikkan nilai $\mathrm{pH}$ sebesar 3,9\% dan dengan bahan penyaring pasir mangan dapat menaikkan $\mathrm{pH}$ sebesar $11,2 \%$ dari $\mathrm{pH}$ awal.

\section{Aplikasi di Perusahaan}

Aplikasi pada perusahaan air mineral di daerah Mempawah adalah dengan menambahkan proses penyaringan dengan menggunakan bahan penyaring karbon aktif pada proses pretreatment sumber air yang akan digunakan untuk memproduksi air mineral. Awalnya dengan penyaringan menggunakan ijuk dan batu apung belum mampu menaikkan $\mathrm{pH}$ hingga sesuai dengan standar mutu. Setelah ditambahkan dengan metode penyaringan menggunakan karbon aktif, diperoleh hasil nilai $\mathrm{pH}$ akhir air baku pada bulan Maret 2020 antara kisaran 6,51-7,29 (memenuhi standar mutu).

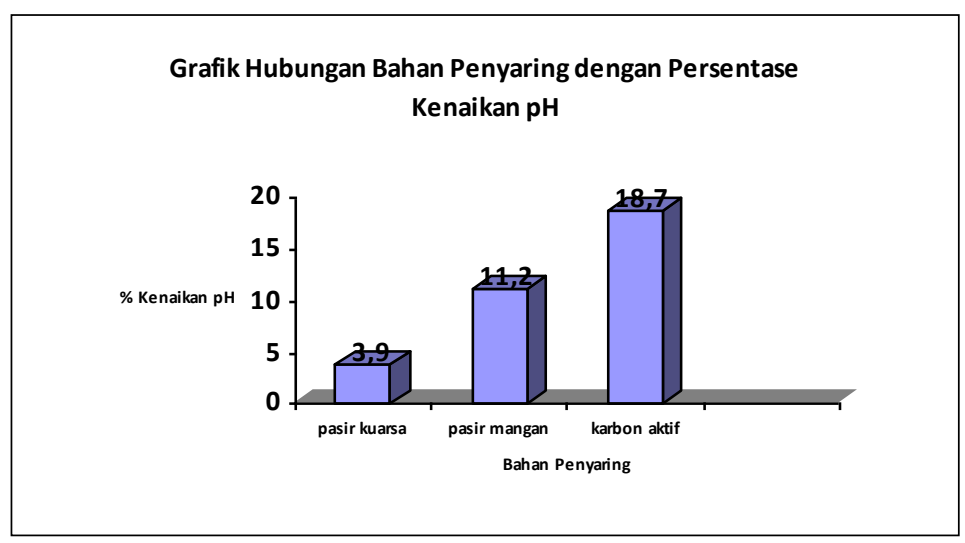

Gambar 9. Grafik Hubungan Bahan Penyaring dengan Persentase Kenaikan pH

40 Jurnal Borneo Akcaya 


\section{KESIMPULAN}

Air yang diperoleh dari sumur bor di daerah Anjongan Kabupaten Mempawah Kalimantan Barat memiliki kualitas $\mathrm{pH}$ di bawah standar baku mutu Peraturan Menteri Kesehatan No. 416/MENKES/IX/1990. Peningkatan kualitas $\mathrm{pH}$ air sumber tersebut yang paling efektif adalah dengan metode penyaringan menggunakan karbon aktif yakni, $\mathrm{pH}$ naik dari 5,68 hingga 6,739 (memenuhi standar 6,5-9), sedangkan dengan penyaringan menggunakan pasir kuarsa menaikkan $\mathrm{pH}$ hingga 5,90 dan dengan penyaringan menggunakan pasir mangan menaikkan pH hingga 6,31. Penyaringan dengan menggunakan karbon aktif sudah banyak dijumpai dan menjadi solusi efektif pada proses pengolahan peningkatan kualitas air baku.

\section{REKOMENDASI}

Bagi perusahaan air mineral yang memiliki masalah air baku yang digunakan mempunyai $\mathrm{pH}$ rendah, maka dapat menggunakan metode penyaringan dengan media penyaring karbon aktif. Hal tersebut terbukti dapat meningkatkan kualitas $\mathrm{pH}$ pada air baku yang digunakan. Selanjutnya, perlu dibuatkan semacam panduan untuk perusahaan air mineral sebagai acuan mengatasi masalah atau kendala baik teknis atau administratif yang dijumpai saat di lapangan serta pemerintah daerah dapat menyampaikan solusi tersebut kepada perusahaan yang lainnya yang memilik kendala yang sama. Pihak ASPADIN (Asosiasi Perusahaan Air Minum Di Indonesia) Daerah Kalimantan Barat khususnya dapat terlebih dahulu mengumpulkan kendala-kendala yang sering dihadapi di lapangan kemudian bekerjasama dengan pihak instansi pemerintah terkait untuk memperoleh solusi pemecahan masalahnya.

\section{UCAPAN TERIMA KASIH}

Penulis mengucapkan terima kasih kepada Kepala Baristand Industri Pontianak, Kepala Seksi Teknologi Industri, tim peneliti dan semua pihak yang telah membantu sehingga penelitian ini dapat terlaksana dan tulisan ini dapat diterbitkan.

\section{DAFTAR PUSTAKA}

Agustina, K. (2019). Pasir Kuarsa dan Arang Aktif Sebagai Media Filtrasi untuk Menurunkan Kandungan Besi (Fe) pada Air Sumur Gali di Dusun Tempursari. Politeknik Kesehatan Yogyakarta.

Asriza, R. O., Pitulima, J., Fabiani, V. A., \& Mahardika, R. G. (2018). Peningkatan Kualitas Air Minum Melalui Metode Penyaringan Bertingkat Berbasis Limbah Kulit Telur di Desa Teru Kabupaten Bangka Tengah. Jurnal ABDI, 4(1), 27-31.

Fadhillah, M., \& Wahyuni, D. (2016). Efektivitas Penambahan Karbon Aktif Cangkang Kelapa Sawit (Elaeis Guineensis) dalam Proses Filtrasi Air Sumur. Jurnal Kesehatan Komunitas, 3(2), 9398.

Heriyani, O., \& Mugisidi, D. (2016). Pengaruh Karbon Aktif dan Zeolit pada $\mathrm{pH}$ Hasil Filtrasi Air Banjir. Prosiding Seminar Nasional Teknologi, Kualitas Dan Aplikasi Fakultas Teknik UHAMKA, 199202.

Majid, F. (2019). Pasir, Zeolit dan Arang Aktif Sebagai Media Filtrasi untuk Menurunkan Kekeruhan, TDS dan E. Coli Air Sungai Selokan Mataram Yogyakarta. Politeknik Kesehatan Yogyakarta.

Mashadi, A., Surendro, B., Rakhmawati, A., \& Amin, M. (2018). Peningkatan Kualitas pH , Fe dan Kekeruhan dari Air Sumur Gali. Jurnal Riset Rekayasa Sipil UNS, 1(2), 105-113. 
Mugiyantoro, A., Rekinagara, I. H., Primaristi, C. D., \& Soesilo, J. (2017). Penggunaan Bahan Alam Zeolit, Pasir Silika, dan Arang Aktif dengan Kombinasi Teknik Shower dalam Filterisasi $\mathrm{Fe}, \mathrm{Mn}$, dan $\mathrm{Mg}$ pada Air Tanah di UPN "Veteran" Yogyakarta. Prosiding Seminar Nasional Kebumian, (10), 11271137.

Ningsih, D. A., Said, I., \& Ningsih, P. (2016). Adsorpsi Logam Timbal $\mathrm{Pb}$ dari Larutannya dengan Menggunakan Adsorben dari Tongkol Jagung. Jurnal Akademika Kimia, 5(2), 55-60.

Oesman, N. M., \& Sugito. (2017). Penurunan Logam Besi dan Mangan Menggunakan Filtrasi Media Zeolit dan Manganese Greensand. Jurnal Teknik WAKTU, 15(2), 57-65.

Pinem, K. I. (2019). Pengaruh Rate Filtrasi dan Ketebalan Media Pasir Silika Terhadap Penurunan Nilai Kekeruhan dan Peningkatan Nilai $\mathrm{pH}$ dalam Filtrasi Air Gambut. Universitas Sumatera Utara.

Quddus, R. (2014). Teknik Pengolahan Air Bersih dengan Sistem Saringan Pasir Lambat (Downflow) yang Bersumber dari Sungai Musi. Teknik Sipil Dan Lingkungan, 2(4), 669-675.

Rahmadhani, D. S. (2014). Perbedaan Keefektifan Media Filter Zeolit dengan Arang Aktif dalam Menurunkan Kadar Kesadahan Air Sumur di Desa Kismoyoso Ngemplak Boyolali. Universitas Muhammadiyah Surakarta.
Situmorang, R., \& Lubis, J. (2017). Analisis Kualitas Air Sumur Bor Berdasarkan Parameter Fisika dan Parameter Kimia di Desa Bagan Deli Kecamatan Medan Belawan. Jurnal Einstein, 5(1), 17-23.

Skoog, D. A., Holler, F. J., \& Crouch, S. R. (1998). Prinsipal of Instrumental Analysis (3th ed.). Saunders College Publishing, New York.

Suhendra, D. S., Marsaulina, I., \& Santi, D. N. (2012). Analisis Kualitas Air Gambut dan Keluhan Kesehatan pada Masyarakat di Dusun Pulo Gombut Desa Rame Baru Kecamatan Kuala Hulu Kabupaten Labuhan Batu Utara Tahun 2012. Universitas Sumatera Utara.

Suhendra, \& Rianto, A. (2017). Karakteristik dan Teknik Pengolahan Air Gambut. Penerbit Cakrawala Budaya.

Trisko, N., Hastiawan, I., \& Eddy, D. R. (2013). Penentuan Kadar Silika dari Pasir Limbah Pertambangan dan Pemanfaatan Pasir Limbah sebagai Bahan Pengisi Bata Beton. Prosiding Seminal Nasioanl Sains Dan Teknologi Nuklir PTNBR - BATAN, 190-196.

Yuliani, N., Nurlela, \& Lestari, N. A. (2017). Kualitas Air Sumur Bor di Perumahan Bekas Persawahan Gunung Putri Jawa Barat. Prosiding Seminar Nasional Dan Gelar Produk, 116-122. 